\title{
GLP-1 vasodilatation in humans with coronary artery disease is not adenosine mediated
}

Muhammad Aetesam-ur-Rahman ${ }^{1,2}$, Joel P. Giblett ${ }^{1}$, Bharat Khialani ${ }^{1}$, Stephen Kyranis ${ }^{1}$, Sophie J. Clarke ${ }^{1}$, Tian X. Zhao ${ }^{1,2}$, Denise M. Braganza' ${ }^{1}$, Sarah C. Clarke ${ }^{1}$, Nick E. J. West ${ }^{1}$, Martin R. Bennett ${ }^{2}$ and Stephen P. Hoole 1* $^{*}$

\begin{abstract}
Background: Incretin therapies appear to provide cardioprotection and improve cardiovascular outcomes in patients with diabetes, but the mechanism of this effect remains elusive. We have previously shown that glucagonlike peptide (GLP)-1 is a coronary vasodilator and we sought to investigate if this is an adenosine-mediated effect.

Methods: We recruited 41 patients having percutaneous coronary intervention (PCI) for stable angina and allocated them into four groups administering a specific study-related infusion following successful PCI: GLP-1 infusion (Group $G)(n=10)$; Placebo, normal saline infusion (Group P) ( $n=11)$; GLP-1 + Theophylline infusion (Group GT) $(n=10)$; and Theophylline infusion (GroupT) $(n=10)$. A pressure wire assessment of coronary distal pressure and flow velocity (thermodilution transit time-Tmn) at rest and hyperaemia was performed after $\mathrm{PCl}$ and repeated following the study infusion to derive basal and index of microvascular resistance (BMR and IMR).

Results: There were no significant differences in the demographics of patients recruited to our study. Most of the patients were not diabetic. GLP-1 caused significant reduction of resting Tmn that was not attenuated by theophylline: mean delta Tmn (SD) group G $-0.23 \mathrm{~s}(0.27)$ versus group GT $-0.18 \mathrm{~s}(0.37), p=0.65$. Theophylline alone (group T) did not significantly alter resting flow velocity compared to group GT: delta Tmn in group T $0.04 \mathrm{~s}(0.15)$, $p=0.30$. The resulting decrease in BMR observed in group G persisted in group GT: $-20.83 \mathrm{mmHg}$ s (24.54 vs.

$-21.20 \mathrm{mmHg} s(30.41), p=0.97$. GLP-1 did not increase circulating adenosine levels in group GT more than group T: delta median adenosine $-2.0 \mathrm{ng} / \mathrm{ml}(-117.1,14.8)$ versus $-0.5 \mathrm{ng} / \mathrm{ml}(-19.6,9.4) ; p=0.60$.

Conclusion: The vasodilatory effect of GLP-1 is not abolished by theophylline and GLP-1 does not increase adenosine levels, indicating an adenosine-independent mechanism of GLP-1 coronary vasodilatation.

Trial registration: The local research ethics committee approved the study (National Research Ethics Service-NRES Committee, East of England): REC reference 14/EE/0018. The study was performed according to institutional guidelines, was registered on http://www.clinicaltrials.gov (unique identifier: NCT03502083) and the study conformed to the principles outlined in the Declaration of Helsinki.
\end{abstract}

\footnotetext{
*Correspondence: s.hoole@nhs.net

${ }^{1}$ Department of Interventional Cardiology, Royal Papworth Hospital,

Papworth Road, Cambridge Biomedical Campus, Cambridge CB2 OAY, UK

Full list of author information is available at the end of the article
}

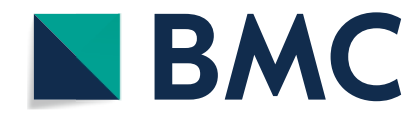

(c) The Author(s) 2021. Open Access This article is licensed under a Creative Commons Attribution 4.0 International License, which permits use, sharing, adaptation, distribution and reproduction in any medium or format, as long as you give appropriate credit to the original author(s) and the source, provide a link to the Creative Commons licence, and indicate if changes were made. The images or other third party material in this article are included in the article's Creative Commons licence, unless indicated otherwise in a credit line to the material. If material is not included in the article's Creative Commons licence and your intended use is not permitted by statutory regulation or exceeds the permitted use, you will need to obtain permission directly from the copyright holder. To view a copy of this licence, visit http://creativecommons.org/licenses/by/4.0/. The Creative Commons Public Domain Dedication waiver (http://creativeco $\mathrm{mmons}$.org/publicdomain/zero/1.0/) applies to the data made available in this article, unless otherwise stated in a credit line to the data. 
Keywords: Glucagon-like peptide 1 (GLP-1), Glucagon-like peptide 1 receptor agonists (GLP-1 RA), Basal microvascular resistance (BMR), Index of microvascular resistance (IMR), Coronary artery disease (CAD)

\section{Background}

Cardiovascular disease is the leading cause of death across the world, predominantly related to atherosclerosis [1]. Diabetes mellitus is one of the major risk factors for premature atherosclerotic coronary artery disease (CAD). Patients with diabetes mellitus are also susceptible to microvascular dysfunction. Endothelium-dependent vasodilation and microvascular coronary flow are frequently abnormal in patients with diabetes [2] and both are partly responsible for the observed increased cardiac morbidity and mortality in patients with diabetes mellitus.

Safety trials of contemporary hypoglycaemic treatments for type- 2 diabetes mellitus have demonstrated beneficial reductions in cardiovascular outcomes [3-6]. One class of drugs-the incretin hormone, Glucagonlike peptide (GLP)-1, stimulates glucose-dependent insulin release and suppresses glucagon resulting in hypoglycaemia [7]. GLP-1, as well as its analogues, such as semaglutide and liraglutide, also improve long-term cardiovascular outcomes with reduction in myocardial infarction and cardiovascular death for patients with diabetes $[3,6,8]$. GLP-1 has been shown to improve left ventricular function during ischaemia-reperfusion injury $[9,10]$. However, the underlying mechanism of these of target GLP-1 effects is not well understood [11], although the GLP-1 receptor is expressed in heart tissue and in particular on vascular smooth muscle cells [12].

Adenosine is a naturally occurring compound that binds to A2A and A2B receptors in the microcirculation [13], exerting a potent vasodilatory effect in vessels below $150 \mu \mathrm{m}$ [14]. Our previous work has shown that GLP-1 causes coronary microvascular vasodilatation and increases coronary flow velocity in humans [15]. Animal studies have shown that alogliptin, an inhibitor of dipeptidyl peptidase (DPP)-4, a ubiquitous enzyme responsible for the degradation of active GLP-1(7-36) to GLP-1(9-36), exerts its cardioprotective effect on infarct size reduction via an adenosine receptor-dependent pathway [16]. A similar adenosinedependent mechanism may be responsible for the cardioprotective effect of GLP-1 in humans, although this has not yet been explored.

We have undertaken a mechanistic study to explore whether GLP-1 causes coronary microvascular vasodilatation via an adenosine-mediated pathway in humans.

\section{Methods \\ Identification and recruitment of patients (Fig. 1)}

One hundred and one patients with stable angina awaiting elective angiography were screened and thirty-one patients were found to be eligible and gave informed written consent. Out of these, nine patients had nonobstructive coronary arteries and therefore, did not require stenting. Two further patients had complex coronary anatomy: one requiring left main bifurcation stenting and the other had surgical revascularization, and therefore were excluded from our study.

Inclusion criteria included patients undergoing elective PCI for stable angina; age above 18 years; and able to give informed consent for the study. Exclusion criteria included any severe co-morbidity with expected life expectancy $<6$ months; use of warfarin, nicorandil, glibenclamide, sitagliptin, vildagliptin, saxagliptin, linagliptin, alogliptin, exenatide, liraglutide, lixisenatide and insulin use; women of child-bearing age; breast-feeding women; myocardial infarction within the previous 3 months in a remote territory; heart failure with ejection fraction $<50 \%$; deranged renal function with eGFR $<60 \mathrm{ml} / \mathrm{min} / 1.73 \mathrm{~m}^{2}$ by Modification of Diet in Renal Disease (MDRD); deranged liver function with alanine transaminase $(\mathrm{ALT})>3$ times upper limit of normal; active peptic ulcer disease confirmed on endoscopy; history of seizures; history of tachyarrhythmias; patients already taking oral theophylline; allergy to theophylline or caffeine.

Twenty patients having percutaneous coronary intervention $(\mathrm{PCI})$ were studied in two groups: those receiving post-PCI infusions of GLP-1 + Theophyline (Group GT) and Theophylline (Group T) respectively. Data from these two groups were compared with historicallyrecruited patients who received GLP-1 infusion (Group G) and placebo (normal saline infusion) (Group P) [15]. Theophylline infusion was used with and without GLP-1 as an adenosine receptor antagonist to determine any adenosine mediated effect of GLP-1.

\section{Procedural details}

All patients received aspirin, $300 \mathrm{mg}$ and clopidogrel, $300 \mathrm{mg}$ preloading, unless they were already established on these antiplatelets. Patients were anticoagulated with a heparin bolus (70-100 U/kg) after arterial sheath insertion (radial or femoral) to achieve an activated clotting time $>250$ s. Iopromide (Ultravist; Bayer HealthCare 


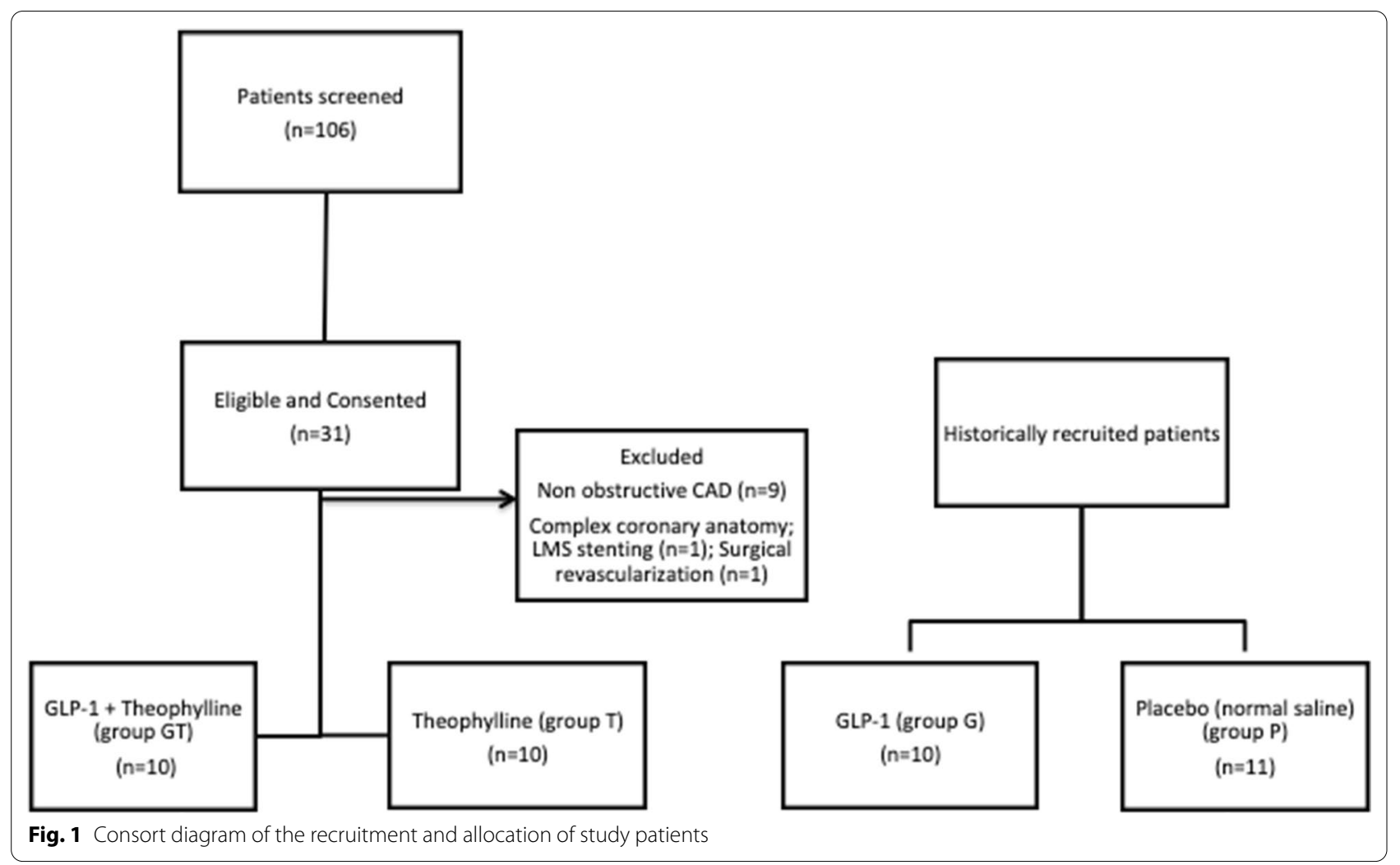

Pharmaceuticals, Leverkusen, Germany) was used as the contrast agent for all cases. The choice of stent and implantation technique was left to operator discretion. Following successful stent implantation baseline bloods were taken to measure serum adenosine levels using a Stop solution.

A Pressure wire X (Abbott Vascular, Santa Clara), connected wirelessly to Coroflow (Coroventis, Uppsala), was positioned and maintained in the distal third of the stented coronary artery. A $0.2 \mathrm{mg}$ bolus of intracoronary glyceryl trinitrate (GTN) was administered, and once steady state coronary haemodynamics were achieved, the baseline coronary pressures [aortic pressure (Pa) and distal wire pressures $(\mathrm{Pd})$ ] and flow velocity measurements were measured. The latter was derived from the reciprocal of mean transit time (Tmn) of an intracoronary injectate of room temperature saline (thermodilution technique) measured in triplicate $[17,18]$. These measurements were repeated following intravenous administration of adenosine at $140 \mathrm{mcg} / \mathrm{kg} / \mathrm{min}$. Coronary wedge pressure $(\mathrm{Pw})$ was measured separately as $\mathrm{Pd}$ during the occlusive coronary balloon inflation.

An intravenous infusion of GLP-1 (1.2 pmol/ kg/ min)(7-36) amide (Bachem AG, Switzerland) and an adenosine receptor inhibitor, theophylline $(5 \mathrm{mg} / \mathrm{kg}$ in $100 \mathrm{ml} 0.9 \% \mathrm{NaCl}$ over $20 \mathrm{~min}$ ) or GLP-1 or Theophylline $(5 \mathrm{mg} / \mathrm{kg}$ in $100 \mathrm{ml} 0.9 \% \mathrm{NaCl}$ over $20 \mathrm{~min}$ ) (Hameln pharma Ltd; UK) or Placebo (100 ml 0.9\% $\mathrm{NaCl}$ over $20 \mathrm{~min}$ ) was infused depending upon patient's group. At the end of infusion, a repeat blood sample was taken from the coronary catheter to measure theophylline and adenosine levels. All the haemodynamic measurements were repeated at rest and hyperaemia after completion of the infusion, usually within $30-\mathrm{min}$ of baseline. At the end of the procedure, the pressure wire was withdrawn to the coronary ostium to enable pressure-drift correction of $\mathrm{Pd}$, if necessary. Pv was assumed to be $5 \mathrm{mmHg}$ in all the patients in this study.

These measurements enabled offline calculation of, basal microvascular resistance $\left(\mathrm{BMR}=\mathrm{Pa} \times \mathrm{Tmn} \times((\mathrm{Pd}-\mathrm{Pw}) /(\mathrm{Pa}-\mathrm{Pw}))_{\text {baseline }}\right)$ and index of microvascular resistance $(\mathrm{IMR}=\mathrm{Pa} \times \mathrm{Tmn} \times((\mathrm{Pd}-\mathrm{Pw}) /(\mathrm{Pa}-\mathrm{Pw})) \quad$ hyperaemia $)$, both corrected for collaterals, fractional flow reserve, $\left(\mathrm{FFR}=(\mathrm{Pd}) /(\mathrm{Pa})_{\text {hyperaemia }}\right)$, coronary flow reserve $\left(\mathrm{CFR}=(\mathrm{Tmn})_{\text {baseline }} /(\mathrm{Tm} n)_{\text {hyperaemia }}\right)$ and collateral flow index by pressure $\left(\mathrm{CFI}_{\mathrm{P}}=(\mathrm{Pw}-\mathrm{Pv}) /(\mathrm{Pa}-\mathrm{Pv})_{\text {baseline }}\right)$ and coronary resistive reserve ratio $(R R R=B M R / I M R)$, as previously described and validated [19, 20] (Fig. 2). 


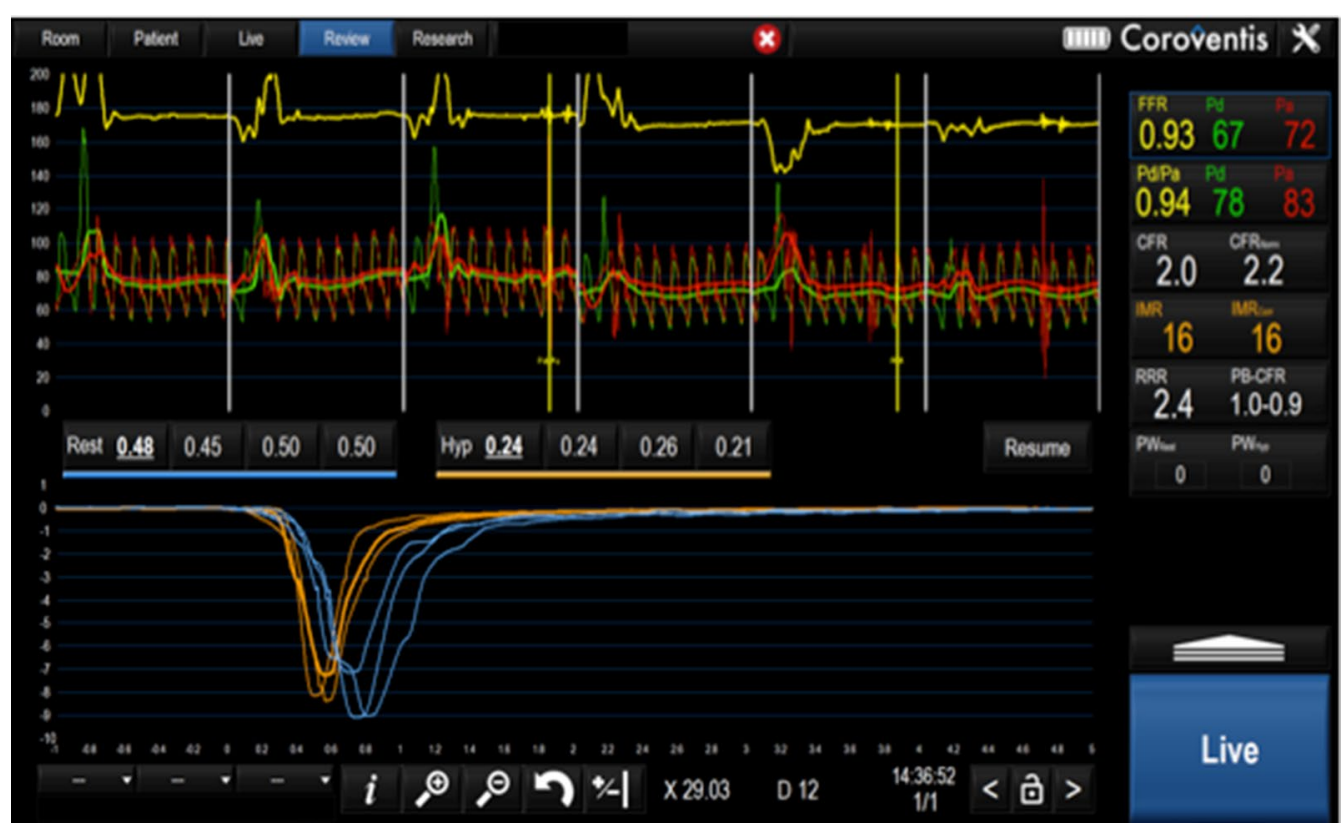

Fig. 2 Example of Coroventis screen during invasive haemodynamic assessment of coronary artery. Blue curves show resting Tmn, orange showing hyperaemic Tmn. Resting as well as hyperaemic pressure and flow indices including Pa, Pd, FFR, IMR and CFR are displayed in the upper right-hand corner

\section{Blood sampling}

Adenosine has a very short half-life and therefore we used a previously published composition of Stop solution to prevent enzymatic breakdown of the extracted serum adenosine samples [21, 22] Blood samples to determine adenosine concentration were collected from the guide catheter, at the completion of PCI and after 20 min of study drug infusion, and placed directly into vacutainers containing Stop solution. This comprised dipyridamole $0.2 \mathrm{mmol} / \mathrm{L}, 4.2 \mathrm{mmol} / \mathrm{L}$ ethylene-diaminetetraacetic acid disodium (Na2 EDTA), erythro-9(2-hydroxy-3-nonyl)-adenine (EHNA) $5 \mathrm{mmol} / \mathrm{L}$, $\alpha, \beta$-methyleneadenosine- $5^{\prime}$-diphosphate (AMPCP) $79 \mathrm{mmol} / \mathrm{L}$, heparin sulfate $1 \mathrm{IU} / \mathrm{mL}$, deoxycoformycin $1 \mu \mathrm{g} / \mathrm{mL}$ in $0.9 \% \mathrm{NaCl}$, all sourced from Merck, UK. After centrifugation, supernatants were deproteinized, and serum adenosine concentration measured by highperformance liquid chromatography. Similarly, blood for theophylline levels was collected from coronary arteries just before the end of infusion and analyzed to confirm therapeutic levels.

\section{Statistical analysis}

On the basis of previous data, we calculated that 10 -paired data sets would provide $80 \%$ power to detect a clinically significant difference $(\triangle \mathrm{BMR}, 20 \mathrm{mmHg} \mathrm{s} ; \mathrm{SD}$, $15 \mathrm{mmHg}$ ) after administration of GLP-1.
Data are given as mean $(\mathrm{SD})$ or median $(\mathrm{Q} 1, \mathrm{Q} 3)$ as appropriate unless otherwise stated. Comparisons were made for any significant differences by unpaired $\mathrm{T}$ test, one-way ANOVA or Kruskal-Wallis test, where appropriate using GraphPad Prism version 8.1.2 (227) (GraphPad Software, La Jolla California USA). Similarly, a simple linear regression was performed between resting adenosine levels and basal coronary flow velocity before and after the study infusion to explore any correlation. A twosided value of $p<0.05$ was deemed significant. Authors had full access to the data and take full responsibility its integrity.

\section{Results}

\section{Baseline characteristics}

Baseline characteristics are summarized in Table 1. All four groups (G, P, GT and T) were well matched although the GT group had more female patients and fewer patients receiving GLP-1 were taking an ACE-inhibitor or angiotensin receptor blocker. Of note, the majority of patients recruited into this study were not diabetic.

\section{Haemodynamic data}

Haemodynamic data are summarized in Table 2 and illustrated in Fig. 2. There were no differences in the baseline or post-infusion heart rate and blood pressure between all the four groups. Similarly, there were no differences in CFR and FFR immediately after stenting and following 
Table 1 Baseline characteristics

\begin{tabular}{lccccc}
\hline & GLP-1 group & Saline group & GLP-1+Theophylline group & Theophylline group & $\boldsymbol{p}$ value \\
\hline Age & $68.30(10.13)$ & $62.30(7.44)$ & $62.20(8.19)$ & $63.10(18.39)$ & $8(80)$ \\
Male & $8(80)$ & $11(100)$ & $4(40)$ & $1(10)$ & 0.62 \\
Diabetes & $1(10)$ & $2(18)$ & $0(0)$ & $5(50)$ & $3(30)$ \\
Hypertension & $6(60)$ & $8(73)$ & $4(40)$ & $7(70)$ & 0.002 \\
Previous MI & $1(10)$ & $8(73)$ & $4(40)$ & $10(10)$ & 0.31 \\
(Ex) Smoker & $7(70)$ & $7(64)$ & $10(10)$ & $8(80)$ & 0.06 \\
Statin & $10(100)$ & $7(100)$ & $4(40)$ & $9(90)$ & 0.09 \\
ACEl/ ARB & $3(30)$ & $8(73)$ & $7(70)$ & 0.13 \\
B Blocker & $4(40)$ & &
\end{tabular}

Data is given as Mean (SD) and $\mathrm{n}(\%)$ where appropriate. $p<0.05$ is considered significant. $p<0.05$ is given as bold

infusion. The basal microvascular resistance (BMR) before infusion was similar in all groups. BMR was significantly lower in the groups receiving GLP-1 (G and GT) after infusion compared to baseline: delta BMR - 20.83 (24.8) and -21.20 (30.1), $p=0.97$ respectively, confirming that theophylline did not attenuate the GLP-1 vasodilatory effect in group GT (Fig. 2). The lower BMR was attributed to a significantly lower (faster) resting Tmn after infusion in the G and GT groups: - $0.23(0.27)$ and $-0.18(0.37)$ respectively, whereas it was essentially unaltered in group T, 0.04 (0.15), $p<0.001$. GLP-1 exhausted the vasodilatory capacity of the microvasculature, with delta median resistive reserve ratio (RRR) in group G: $-1.00(-2.95,-0.01)$ and in group GT: $-0.88(-3.79,-0.27)$ compared to 2.01 $(0.23,3.57)$ in group $\mathrm{S}$ and $-0.16(-1.06,0.61)$ in group $\mathrm{T}$, $p=0.03$, (Fig. 3). Similarly, delta CFR was lower in group G: $-0.89(-2.01,0.97)$ versus the other three groups. There was no significant difference in IMR or delta IMR across all the four groups.

\section{Biochemical data}

The mean theophylline levels measured at the end of infusion were in the therapeutic range $(10-20 \mathrm{mcg} / \mathrm{ml})$ and similar between GT and T groups: $13.58 \mathrm{mcg} / \mathrm{ml}(4.48)$ versus $15.05 \mathrm{mcg} / \mathrm{ml}$ (2.15), $p=0.40$. There was no difference in delta median adenosine levels after infusion between the two groups: GT, $-2.00 \mathrm{ng} / \mathrm{ml}(-117.1,14.8)$ versus $\mathrm{T},-0.50 \mathrm{ng} / \mathrm{ml}(-19.6,9.4), p=0.60$.

\section{Correlation of basal adenosine and Tmn}

There was no correlation found in the measured adenosine levels and basal coronary flow velocity, before or after the study infusion (Additional file 1).

\section{Discussion}

This study demonstrates that GLP-1 does not increase circulating adenosine levels, and that GLP-1-induced reduction in Tmn and BMR at rest was not attenuated by co-administration of the adenosine receptor antagonist theophylline. This indicates that GLP-1 exerts an adenosine-independent vasodilatatory effect.

GLP-1 receptor agonists are associated with improved long-term cardiovascular outcomes $[6,23]$ and a variable reduction in infarct size in previous human studies $[8,9,24,25]$. Adenosine is a naturally occurring vasodilator and is a cellular mediator of cardioprotective ischaemic conditioning (IC) [26] by directly activating phospholipase $\mathrm{C}$ and/or protein kinase $\mathrm{C}$ (PKC) via adenosine 1 receptors (A1R), which are widely present in myocardial tissue $[27,28]$. GLP-1 activates protein kinase A (PKA) along with other physiologically active metabolites at a cellular level [29]. The cross talk between PKC and PKA is well established and activation of PKA could in theory result in reduction of the activation threshold of $\mathrm{PKC}$, thus potentiating the cardiac effects of adenosine [30,31]. This PKC and PKA interaction has been postulated to be the underlying physiological mechanism of adenosine-mediated cardioprotection by GLP-1 in an animal model [16].

We have previously shown that GLP-1 attenuates ischaemia-induced LV dysfunction and the derived cardioprotection, but unlike conditioning is not associated with a potassium adenosine tri-phasphate (KATP) channel-dependent pathway [10] and is also independent of changes in cardiac substrate use [9]. More recently, we have shown that GLP-1 is a coronary vasodilator, possibly resulting indirectly from lusitropic forces "opening" the myocardial microcirculation in diastole as a result of ventricular-microcirculatory interactions $[15,32,33]$. Although in the same study we confirmed GLP-1 receptor(R) expression on ventricular myocytes, others have suggested that GLP-1R expression is confined to atrial cardiomyocytes [34] and vascular smooth muscle [12]. Therefore, we were keen to explore if GLP-1 could cause vasodilatation via an adenosine-mediated effect on the microcirculation, 
Table 2 Haemodynamic data of study patients

\begin{tabular}{|c|c|c|c|c|c|}
\hline Variable & GLP-1 group & Saline group & $\begin{array}{l}\text { GLP-1 + Theophylline } \\
\text { group }\end{array}$ & Theophylline group & $p$ value \\
\hline \multicolumn{6}{|l|}{ Immediate post $\mathrm{PCl}$} \\
\hline \multicolumn{6}{|l|}{ Baseline } \\
\hline Heart rate (bpm) & $65.6(8.9)$ & $79.3(32.1)$ & $68.5(9.0)$ & $62.6(4.6)$ & 0.21 \\
\hline Systolic BP (mmHg) & $131.8(27.5)$ & $133.1(35.9)$ & $138.3(20.3)$ & $133.4(25.7)$ & 0.91 \\
\hline Diastolic BP (mmHg) & $59.2(11.3)$ & $72.3(17.1)$ & $64.8(9.4)$ & $66.3(9.9)$ & 0.14 \\
\hline $\mathrm{Pa} \mathrm{mmHg}$ & $89.7(16.5)$ & $97.3(23.4)$ & $95.1(10.8)$ & $97.6(14.9)$ & 0.58 \\
\hline $\mathrm{Pd} \mathrm{mmHg}$ & $84.6(16.5)$ & $93.3(24.1)$ & $90.5(9.6)$ & $94.3(15.1)$ & 0.49 \\
\hline $\mathrm{Pd} / \mathrm{Pa}$ & $0.94(0.04)$ & $0.95(0.04)$ & $0.95(0.04)$ & $0.96(0.04)$ & 0.51 \\
\hline $\operatorname{Tmn}(\mathrm{s})$ & $0.87(0.39)$ & $0.48(0.23)$ & $0.85(0.79)$ & $0.48(0.40)$ & 0.16 \\
\hline BMR & $76.3(37.9)$ & $45.9(34.7)$ & $78.5(70.8)$ & $46.6(44.8)$ & 0.25 \\
\hline \multicolumn{6}{|l|}{ Hyperaemia } \\
\hline $\mathrm{Pa}(\mathrm{mmHg})$ & $81.2(17.8)$ & $90.6(19.9)$ & $89.9(14.1)$ & $86.2(17.3)$ & 0.49 \\
\hline $\mathrm{Pd}(\mathrm{mmHg})$ & $71.9(14.9)$ & $81.6(19.7)$ & $80.0(11.7)$ & $79.5(16.0)$ & 0.44 \\
\hline FFR & $0.88(0.06)$ & $0.89(0.08)$ & $0.89(0.05)$ & $0.92(0.07)$ & 0.41 \\
\hline $\operatorname{Tmn}(\mathrm{s})$ & $0.24(0.10)$ & $0.20(0.07)$ & $0.21(0.10)$ & $0.24(0.17)$ & 0.71 \\
\hline CFR & $4.0(2.2)$ & $2.4(0.8)$ & $4.6(4.2)$ & $2.1(0.8)$ & 0.16 \\
\hline IMR & $16.3(10.2)$ & $15.6(5.8)$ & $16.5(9.7)$ & $18.8(14.2)$ & 0.86 \\
\hline CFIP & $0.15(0,0.23)$ & $0.09(0,0.21)$ & $0.12(0.05,0.27)$ & $0.18(0.06,0.29)$ & 0.78 \\
\hline RRR & $5.1(1.9)$ & $2.9(1.3)$ & $5.5(5.4)$ & $2.6(1.2)$ & 0.13 \\
\hline \multicolumn{6}{|l|}{ Post Infusion } \\
\hline \multicolumn{6}{|l|}{ Baseline } \\
\hline Heart rate (bpm) & $63.0(13.9)$ & $68.7(11.9)$ & $68.8(8.4)$ & $66.0(12.3)$ & 0.58 \\
\hline Systolic BP (mmHg) & $138.3(22.3)$ & $140.1(26.1)$ & $134.7(21.5)$ & $133.0(23.1)$ & 0.81 \\
\hline Diastolic BP (mmHg) & $63.4(7.8)$ & $71.8(15.3)$ & $68.3(13.2)$ & $64.8(13.1)$ & 0.36 \\
\hline $\mathrm{Pa}(\mathrm{mmHg})$ & $90.8(16.6)$ & $89.6(15.4)$ & $92.6(15.3)$ & $94.9(8.6)$ & 0.77 \\
\hline $\mathrm{Pd}(\mathrm{mmHg})$ & $84.9(15.9)$ & $86.4(16.7)$ & $88.6(14.2)$ & $91.4(9.0)$ & 0.65 \\
\hline $\mathrm{Pd} / \mathrm{Pa}$ & $0.93(0.03)$ & $0.96(0.04)$ & $0.96(0.04)$ & $0.96(0.03)$ & 0.11 \\
\hline $\operatorname{Tmn}(\mathrm{s})$ & $0.63(0.27)$ & $0.83(0.41)$ & $0.66(0.54)$ & $0.52(0.39)$ & 0.37 \\
\hline BMR & $55.4(30.4)$ & $66.7(37.2)$ & $57.3(48.5)$ & $47.8(38.8)$ & 0.64 \\
\hline \multicolumn{6}{|l|}{ Hyperaemia } \\
\hline $\mathrm{Pa}(\mathrm{mmHg})$ & $80.1(16.7)$ & $89.6(15.4)$ & $90.5(10.9)$ & $89.5(23.9)$ & 0.38 \\
\hline $\mathrm{Pd}(\mathrm{mmHg})$ & $71.9(15.3)$ & $76.2(17.1)$ & $88.6(14.2)$ & $82.6(19.2)$ & 0.14 \\
\hline FFR & $0.89(0.06)$ & $0.89(0.08)$ & $0.93(0.03)$ & $0.93(0.06)$ & 0.24 \\
\hline $\operatorname{Tmn}(\mathrm{s})$ & $0.29(0.21)$ & $0.21(0.07)$ & $0.25(0.14)$ & $0.26(0.13)$ & 0.53 \\
\hline CFR & $3.0(2.4)$ & $4.2(2.0)$ & $2.6(1.5)$ & $2.1(1.1)$ & 0.11 \\
\hline IMR & $19.7(14.6)$ & $15.0(6.2)$ & $20.1(11.4)$ & $21.2(12.2)$ & 0.49 \\
\hline CFIP & $0.17(0.00,0.29)$ & $0.08(0.00,0.23)$ & $0.13(0.05,0.29)$ & $0.19(0.07,0.28)$ & 0.96 \\
\hline RRR & $3.61(2.5)$ & $4.73(2.3)$ & $2.76(1.6)$ & $2.46(1.5)$ & 0.09 \\
\hline
\end{tabular}

Results expressed as mean (SD). Tmn-transit time; $\mathrm{Pa}$-aortic pressure; $\mathrm{Pd}$ - distal coronary pressure; $\mathrm{BMR}$-basal microcirculatory resistance $=\mathrm{Pa} * \mathrm{Tmn}$ baseline ${ }^{*}((\mathrm{Pd}-\mathrm{Pw}) /(\mathrm{Pa}-\mathrm{Pw})) ; \mathrm{IMR}$-index of microcirculatory resistance $=\mathrm{Pa}{ }^{*} \mathrm{Tmn}_{\text {hyperemic }}{ }^{*}((\mathrm{Pd}-\mathrm{Pw}) /(\mathrm{Pa}-\mathrm{Pw}))$; FFR- fractional flow reserve $=\mathrm{Pd} / \mathrm{Pa}$ hyperemic $; \mathrm{CFR}-$ coronary flow reserve $=\mathrm{Tmn}_{\text {baseline }} / \mathrm{Tmn}_{\text {hyperemic }} \mathrm{CFI}$-Collateral flow index by pressure $=(\mathrm{PW}-\mathrm{Pv}) /(\mathrm{Pa}-\mathrm{Pv})_{\text {baseline }}$ and coronary resistive reserve ratio $(\mathrm{RRR})=\mathrm{BMR} /$ IMR

indirectly improving ventricular function via the Gregg effect [32].

We clearly demonstrate in this study that GLP-1 vasodilatation is unlikely to be the mediated by adenosine. GLP-1 increases basal coronary flow velocity and reduces BMR irrespective of theophylline. GLP-1 exhausts vasodilatory capacity, such that response to exogenous adenosine is blunted as measured by a reduction in CFR and RRR. Theophylline has been used to investigate adenosine-mediated effect of other therapies; it is a potent adenosine receptor inhibitor at 

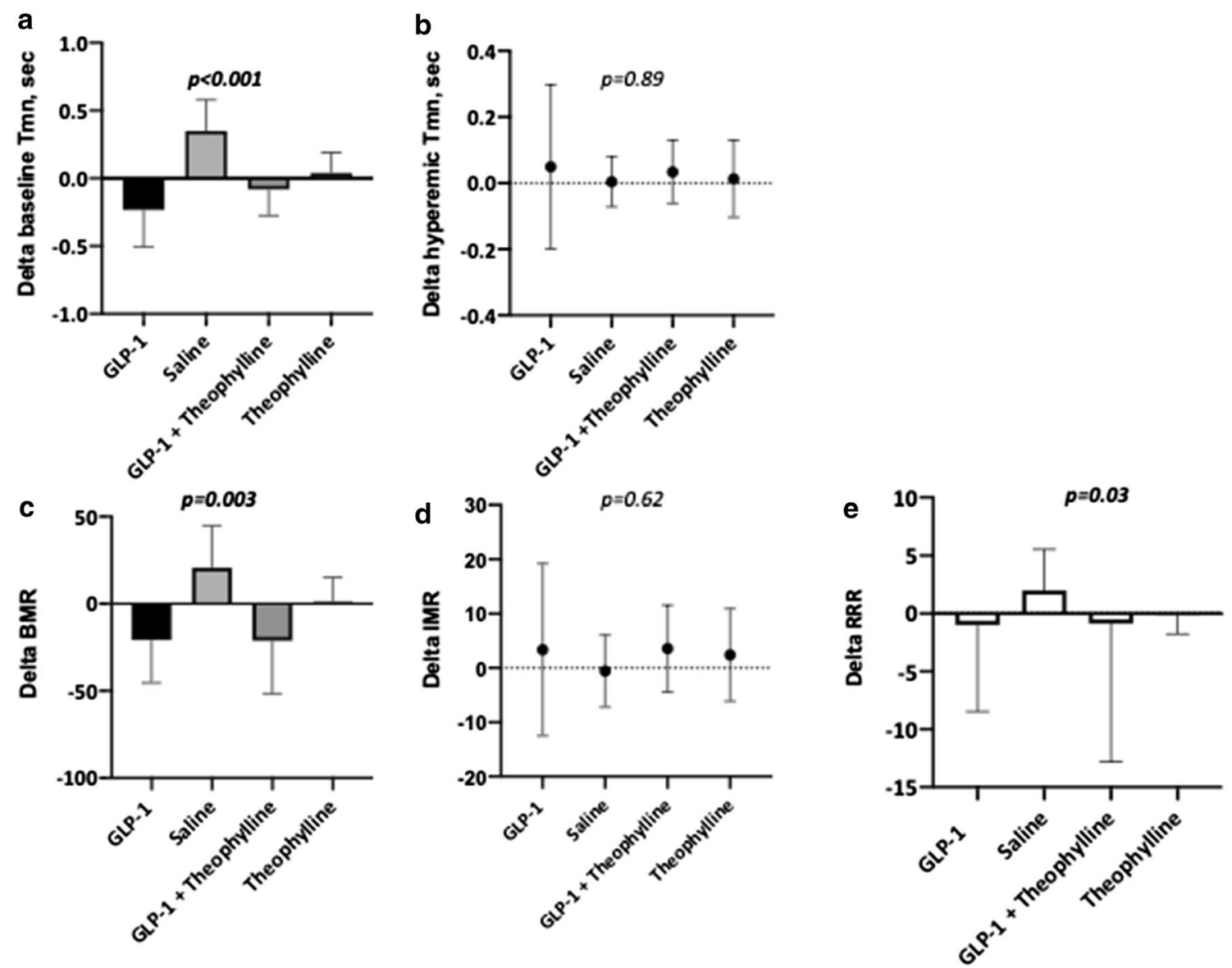

Fig. 3 Comparison of change in thermodilution time, Tmn at rest (a) and hyperemia (b); basal microvascular resistance, BMR (c); index of microvascular resistance, IMR (d) and resistive reserve ratio, RRR (e) after each infusion. $p<\mathbf{0 . 0 5}$ is given as bold

levels achieved in our study [35]. In addition, the adenosine levels remained unchanged after GLP-1 infusion.

Coronary microvascular dysfunction (CMD) is associated with worse clinical outcomes [36] and microvascular injury at the time of elective PCI is associated with procedure-related myocardial infarction and a worse prognosis [37]. GLP-1 improves coronary flow after stenting [15], decreases periprocedural left ventricular dysfunction and stunning [8, 38, 39], and improves immediate as well as long-term cardiovascular outcomes after revascularization for coronary ischemia [24]. GLP-1 and its analogues should be further investigated for symptomatic as well as prognostic benefit in patients with CMD. Furthermore; GLP-1 has the potential to be a much simpler addition to the currently utilized armamentarium of cardioprotective strategies for patients at high risk of peri-procedural cardiovascular events [11].

\section{Limitations}

There are several limitations in our study. Firstly, this was not a randomized controlled trial but was performed in two phases by block allocation to understand the mechanistic effects of GLP-1 on coronary physiology. However, the patients were unselected and sequentially recruited if eligible, and we believe this prevented significant bias. Second, we studied the coronary vasodilatory effects of GLP-1 following PCI. Coronary physiology may not be stable at this time due to reactive hyperaemia and microvascular stunning $[15,40]$; however, we mitigated this by waiting for reactive hyperaemia to dissipate before making our measurements. Third, we used a surrogate for coronary flow-Tmn measured by a pressure wire based coronary thermodilution technique. This is a well-validated and accurate technique, that is comparable to other measures of coronary flow velocity $[17,18]$. Fourth, we did not 
perform invasive measurements to confirm our previously published protective effects of GLP-1 on periprocedural LV dysfunction and also assumed $\mathrm{Pv}$ to be $5 \mathrm{mmHg}$ in our patients; this was for logistical reasons. Fifth, patients with diabetes were under-represented in our study and the GLP-1 effect in this group needs confirming. Finally, we only measured adenosine levels in the latter two prospectively-recruited GT and T groups due to logistical reasons. Endogenous adenosine levels did not correlate with resting coronary flow velocity. The reason for this is unclear but may be due to difficulties in assaying adenosine and also that the sample site was at the level of the coronary ostium rather than at the microcirulation. Theophylline is reported to increase local serum catecholamine levels by offtarget effects, which may also blunt adenosine mediated vasodilatation [41]. It is also possible that different batches of Stop solution may explain some of the intergroup differences in adenosine levels, although patientlevel changes in adenosine level were assayed with the same Stop solution and remain valid.

\section{Conclusion}

The coronary vasodilatory effect of GLP-1 appears to be independent of adenosine. Further studies are required to understand the mechanism of the cardioprotective effects of GLP-1.

\begin{abstract}
Abbreviations
GLP-1: Glucagon-like peptide-1; GLP-1 RA: Glucagon-like peptide 1 receptor agonists; DPP-4: Dipeptidyl peptidase-4; PCl: Percutaneous coronary intervention; CAD: Coronary artery disease; CMD: Coronary microvascular dysfunction; MDRD: Modification of Diet in Renal Disease; ALT: Alanine transaminase; GTN: Glyceryl trinitrate; Tmn: Thermodilution transit time; Pa: Aortic pressure; Pd: Coronary distal pressures; Pw: Coronary wedge pressure; Pv: Central venous pressure; CFR: Coronary flow reserve; RRR: Resistive reserve ratio; BMR: Basal microvascular resistance; IMR: Index of microvascular resistance.
\end{abstract}

\section{Supplementary Information}

The online version contains supplementary material available at https://doi. org/10.1186/s12872-021-02030-5.

Additional file 1: Supplemetary Figure. Sactterplot of the relationship between $\mathrm{A}$ ) pre and $\mathrm{B}$ ) post infusion adenosine concentration and $\mathrm{Tmn}_{\text {rest }}$.

\section{Acknowledgements}

We thank all the staff and patients of Royal Papworth hospital who took part in this study.

\section{Authors' contributions}

All the authors participated in the study design and approval, data collection, data analysis and preparation of manuscript. Moreover, they undertook critical review of the manuscript and approved it for publication. All authors read and approved the final manuscript.
Funding

This study was funded by NIHR Cambridge Biomedical Research Centre.

\section{Availability of data and materials}

The datasets used and/or analysed during the current study are available from the corresponding author on reasonable request.

\section{Declarations}

\section{Ethics approval and consent to participate}

The local research ethics committee (National Research Ethics Service-NRES Committee, East of England) approved the study: REC reference 14/EE/0018. All participants signed an informed consent to participate in the study and their anonymised data to be used in the subsequent publication. The study was performed according to institutional guidelines, was registered on http:// www.clinicaltrials.gov (unique identifier: NCT03502083) and the study conformed to the principles outlined in the Declaration of Helsinki.

\section{Consent for publication}

Not applicable.

\section{Competing interests}

The authors declare that they had no competing interests at the time of study to declare. NW has been appointed as chief medical officer for Abbott Vascular since then.

\section{Author details}

${ }^{1}$ Department of Interventional Cardiology, Royal Papworth Hospital, Papworth Road, Cambridge Biomedical Campus, Cambridge CB2 OAY, UK. ${ }^{2}$ Division of Cardiovascular Medicine, University of Cambridge, Cambridge, UK.

Received: 12 August 2020 Accepted: 21 April 2021

Published online: 01 May 2021

\section{References}

1. Timmis A, Townsend N, Gale CP, Torbica A, Lettino M, Petersen SE, Mossialos EA, Maggioni AP, Kazakiewicz D, May HT, et al. European Society of Cardiology: cardiovascular disease statistics 2019. Eur Heart J. 2020;41(1):12-85

2. Johnstone MT, Creager SJ, Scales KM, Cusco JA, Lee BK, Creager MA. Impaired endothelium-dependent vasodilation in patients with insulindependent diabetes mellitus. Circulation. 1993;88(6):2510-6.

3. Marso SP, Bain SC, Consoli A, Eliaschewitz FG, Jodar E, Leiter LA, Lingvay I, Rosenstock J, Seufert J, Warren ML, et al. Semaglutide and cardiovascular outcomes in patients with type 2 diabetes. N Engl J Med. 2016;375(19):1834-44.

4. Neal B, Perkovic V, Mahaffey KW, de Zeeuw D, Fulcher G, Erondu N, Shaw W, Law G, Desai M, Matthews DR. Canagliflozin and cardiovascular and renal events in type 2 diabetes. N Engl J Med. 2017;377(7):644-57.

5. Wanner C, Lachin JM, Inzucchi SE, Fitchett D, Mattheus M, George J, Woerle HJ, Broedl UC, von Eynatten M, Zinman B. Empagliflozin and clinical outcomes in patients with type 2 diabetes mellitus, established cardiovascular disease, and chronic kidney disease. Circulation. 2018;137(2):119-29.

6. Marso SP, Daniels GH, Brown-Frandsen K, Kristensen P, Mann JFE, Nauck MA, Nissen SE, Pocock S, Poulter NR, Ravn LS, et al. Liraglutide and cardiovascular outcomes in type 2 diabetes. N Engl J Med. 2016;375(4):311-22.

7. Drucker DJ, Nauck MA. The incretin system: glucagon-like peptide-1 receptor agonists and dipeptidyl peptidase-4 inhibitors in type 2 diabetes. Lancet. 2006;368(9548):1696-705.

8. Read PA, Hoole SP, White PA, Khan FZ, O'Sullivan M, West NE, Dutka DP. A pilot study to assess whether glucagon-like peptide-1 protects the heart from ischemic dysfunction and attenuates stunning after coronary balIoon occlusion in humans. Circ Cardiovasc Interv. 2011;4(3):266-72.

9. McCormick LM, Hoole SP, White PA, Read PA, Axell RG, Clarke SJ, O'Sullivan $M$, West NEJ, Dutka DP. Pre-treatment with glucagon-like Peptide-1 protects against ischemic left ventricular dysfunction and stunning without 
a detected difference in myocardial substrate utilization. JACC Cardiovasc Interv. 2015;8(2):292-301.

10. Giblett JP, Axell RG, White PA, Clarke SJ, McCormick L, Read PA, Reinhold J, Brown AJ, O'Sullivan M, West NE, et al. Glucagon-like peptide-1 derived cardioprotection does not utilize a KATP-channel dependent pathway: mechanistic insights from human supply and demand ischemia studies. Cardiovasc Diabetol. 2016:15:99.

11. Giblett JP, Clarke SJ, Dutka DP, Hoole SP. Glucagon-like peptide-1: a promising agent for cardioprotection during myocardial ischemia. JACC Basic Transl Sci. 2016;1 (4):267-76.

12. Richards P, Parker HE, Adriaenssens AE, Hodgson JM, Cork SC, Trapp S, Gribble FM, Reimann F. Identification and characterization of GLP-1 receptor-expressing cells using a new transgenic mouse model. Diabetes. 2014;63(4):1224-33.

13. Shryock JC, Belardinelli L. Adenosine and adenosine receptors in the cardiovascular system: biochemistry, physiology, and pharmacology. Am J Cardiol. 1997;79(12a):2-10

14. Kanatsuka H, Lamping KG, Eastham CL, Dellsperger KC, Marcus ML. Comparison of the effects of increased myocardial oxygen consumption and adenosine on the coronary microvascular resistance. Circ Res. 1989;65(5):1296-305.

15. Clarke SJ, Giblett JP, Yang LL, Hubsch A, Zhao T, Aetesam-Ur-Rahman M, West NEJ, O'Sullivan M, Figg N, Bennett M, et al. GLP-1 is a coronary artery vasodilator in humans. J Am Heart Assoc. 2018;7(22):e010321.

16. Ihara M, Asanuma H, Yamazaki S, Kato H, Asano Y, Shinozaki Y, Mori H, Minamino T, Asakura M, Sugimachi M, et al. An interaction between glucagon-like peptide-1 and adenosine contributes to cardioprotection of a dipeptidyl peptidase 4 inhibitor from myocardial ischemia-reperfusion injury. Am J Physiol Heart Circ Physiol. 2015;308(10):H1287-97.

17. Fearon WF, Farouque HM, Balsam LB, Caffarelli AD, Cooke DT, Robbins RC, Fitzgerald PJ, Yeung AC, Yock PG. Comparison of coronary thermodilution and Doppler velocity for assessing coronary flow reserve. Circulation. 2003:108(18):2198-200

18. De Bruyne B, Pijls NH, Smith L, Wievegg M, Heyndrickx GR. Coronary thermodilution to assess flow reserve: experimental validation. Circulation. 2001;104(17):2003-6.

19. Hoole SP, Jaworski C, Brown AJ, McCormick LM, Agrawal B, Clarke SC, West NE. Serial assessment of the index of microcirculatory resistance during primary percutaneous coronary intervention comparing manual aspiration catheter thrombectomy with balloon angioplasty (IMPACT study): a randomised controlled pilot study. Open Heart. 2015:2(1):e000238.

20. Layland J, Carrick D, McEntegart M, Ahmed N, Payne A, McClure J, Sood A, McGeoch R, Maclsaac A, Whitbourn R, et al. Vasodilatory capacity of the coronary microcirculation is preserved in selected patients with non-ST-segment-elevation myocardial infarction. Circ Cardiovasc Interv. 2013;6(3):231-6

21. Bonello L, Laine M, Kipson N, Mancini J, Helal O, Fromonot J, Gariboldi $\mathrm{V}$, Condo J, Thuny F, Frere C, et al. Ticagrelor increases adenosine plasma concentration in patients with an acute coronary syndrome. J Am Coll Cardiol. 2014;63(9):872-7.

22. Casal S, Oliveira MB, Ferreira MA. Development of an HPLC/diodearray detector method for simultaneous determination of trigonelline, nicotinic acid, and caffeine in coffee. J Liq Chromatogr Relat Technol. 1998:21(20):3187-95.

23. Marso SP, Bain SC, Consoli A, Eliaschewitz FG, Jódar E, Leiter LA, Lingvay I, Rosenstock J, Seufert J, Warren ML, et al. Semaglutide and cardiovascular outcomes in patients with type 2 diabetes. N Engl I Med. 2016;375(19):1834-44

24. Lønborg J, Vejlstrup N, Kelbæk H, Bøtker HE, Kim WY, Mathiasen AB, Jørgensen E, Helqvist S, Saunamäki K, Clemmensen P, et al. Exenatide reduces reperfusion injury in patients with ST-segment elevation myocardial infarction. Eur Heart J. 2012;33(12):1491-9.

25. Giblett JP, Clarke S, Zhao T, McCormick LM, Braganza DM, Densem CG O'Sullivan M, Adlam D, Clarke SC, Steele J, et al. The role of Glucagon-like peptide 1 loading on periprocedural myocardial infarction during elective PCI (GOLD-PCI study): a randomized, placebo-controlled trial. Am Heart J. 2019:215:41-51.

26. Liu GS, Thornton J, Van Winkle DM, Stanley AW, Olsson RA, Downey JM. Protection against infarction afforded by preconditioning is mediated by A1 adenosine receptors in rabbit heart. Circulation. 1991;84(1):350-6.

27. Cohen MV, Downey JM. Adenosine: trigger and mediator of cardioprotection. Basic Res Cardiol. 2008;103(3):203-15.

28. Kitakaze M, Funaya H, Minamino T, Node K, Sato H, Ueda Y, Okuyama Y, Kuzuya T, Hori M, Yoshida K. Role of protein kinase C-alpha in activation of ecto-5'-nucleotidase in the preconditioned canine myocardium. Biochem Biophys Res Commun. 1997;239(1):171-5.

29. Campbell JE, Drucker DJ. Pharmacology, physiology, and mechanisms of incretin hormone action. Cell Metab. 2013;17(6):819-37.

30. Santafé MM, Garcia N, Lanuza MA, Tomàs M, Tomàs J. Interaction between protein kinase $\mathrm{C}$ and protein kinase $\mathrm{A}$ can modulate transmitter release at the rat neuromuscular synapse. J Neurosci Res. 2009;87(3):683-90.

31. Yao L, Fan P, Jiang Z, Gordon A, Mochly-Rosen D, Diamond I. Dopamine and ethanol cause translocation of epsilonPKC associated with epsilonRACK: cross-talk between CAMP-dependent protein kinase $A$ and protein kinase C signaling pathways. Mol Pharmacol. 2008;73(4):1105-12.

32. Gregg DE. Effect of coronary perfusion pressure or coronary flow on oxygen usage of the myocardium. Circ Res. 1963;13(6):497-500.

33. Westerhof N, Boer C, Lamberts RR, Sipkema P. Cross-talk between cardiac muscle and coronary vasculature. Physiol Rev. 2006;86(4):1263-308.

34. Pyke C, Knudsen LB. The glucagon-like peptide-1 receptor-or not? Endocrinology. 2013;154(1):4-8.

35. Wittfeldt A, Emanuelsson H, Brandrup-Wognsen G, van Giezen J J, Jonasson J, Nylander S, Gan LM. Ticagrelor enhances adenosineinduced coronary vasodilatory responses in humans. J Am Coll Cardiol. 2013:61(7):723-7.

36. Pepine CJ, Anderson RD, Sharaf BL, Reis SE, Smith KM, Handberg EM, Johnson BD, Sopko G, Bairey Merz CN. Coronary microvascular reactivity to adenosine predicts adverse outcome in women evaluated for suspected ischemia results from the National Heart, Lung and Blood Institute WISE (Women's Ischemia Syndrome Evaluation) study. J Am Coll Cardiol. 2010;55(25):2825-32.

37. Zeitouni M, Silvain J, Guedeney P, Kerneis M, Yan Y, Overtchouk P, Barthelemy O, Hauguel-Moreau M, Choussat R, Helft G, et al. Periprocedural myocardial infarction and injury in elective coronary stenting. Eur Heart J. 2018;39(13):1100-9.

38. Read PA, Khan FZ, Heck PM, Hoole SP, Dutka DP. DPP-4 inhibition by sitagliptin improves the myocardial response to dobutamine stress and mitigates stunning in a pilot study of patients with coronary artery disease. Circ Cardiovasc Imaging. 2010;3(2):195-201.

39. McCormick LM, Heck PM, Ring LS, Kydd AC, Clarke SJ, Hoole SP, Dutka DP. Glucagon-like peptide-1 protects against ischemic left ventricular dysfunction during hyperglycemia in patients with coronary artery disease and type 2 diabetes mellitus. Cardiovasc Diabetol. 2015;14:102.

40. Hoole SP, Heck PM, White PA, Read PA, Khan SN, West NE, O'Sullivan M, Dutka DP. Stunning and cumulative left ventricular dysfunction occurs late after coronary balloon occlusion in humans insights from simultaneous coronary and left ventricular hemodynamic assessment. JACC Cardiovasc Interv. 2010;3(4):412-8.

41. Minamino T, Kitakaze M, Morioka T, Node K, Shinozaki Y, Chujo M, Mori H, Takeda $\mathrm{H}$, Inoue $\mathrm{M}$, Hori M, et al. Bidirectional effects of aminophylline on myocardial ischemia. Circulation. 1995;92(5):1254-60.

\section{Publisher's Note}

Springer Nature remains neutral with regard to jurisdictional claims in published maps and institutional affiliations. 